\title{
Growth, Nutrient Utilization and Physico-Chemical Responses in the Monoculture of Juvenile Clarias Gariepinus to Increasing Stocking Density
}

\author{
O. A. Oyelese ${ }^{1}$, Olutimehin, I.O2, And Akomolafe, M. O.3 \\ Department of Aquaculture and Fisheries Management University of Ibadan Ibadan, Nigeria.
}

\begin{abstract}
A ten (10) week feeding trial was undertaken to assess the growth performance and nutrient utilization of Juvenile Clarias gariepinus of average weight range 250gm - 300gm stocked under 5 different treatments $\left(10\left(\right.\right.$ trt $\left._{1}\right) 15$ (trt $\left.t_{2}\right) 20$ (trt $\left.t_{3}\right) 25$ (trt $\left.t_{4}\right)$ and 30(trt $)_{5}$ Juvenile Clarias gariepinus/250 litre bowl (under laboratory conditions) with increasing stocking densities, along with monitoring the following physico-chemical factors ( $\mathrm{pH}$, Temperature $\left({ }^{\circ} \mathrm{C}\right.$ ), Dissolved oxygen (DO) in mg/litre, Ammonia (p.p.m), Alkalinity (p.p.m) and dissolved carbon dioxide $\left(\mathrm{CO}_{2}\right.$ in $\mathrm{mg} /$ /litre). The increasing stocking density caused a decrease in value of the final fish body crude protein $\operatorname{Trt}_{1}(75.18 \%)>\operatorname{Trt}_{2}\left(73.9>\operatorname{Trt}_{3}(72.71 \%)>\operatorname{Trt}_{4}(71.21 \%)>\operatorname{Trt}_{5}(70.19 \%)\right.$. A similar trend was followed in the specific growth rate (SGR) pattern decreasing from $0.20\left(\operatorname{Trt}_{1}\right)$ to $0.015\left(\operatorname{Trt}_{5}\right)$

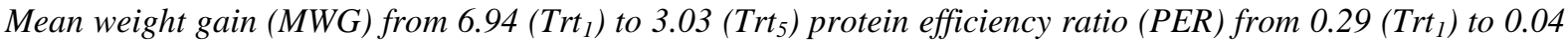
$\left(\operatorname{Trt}_{5}\right)$, productive protein value (PPV) from $0.24\left(\operatorname{Trt}_{1}\right)$ to $0.04\left(\operatorname{Trt}_{5}\right)$ and Net protein utilization (NPU) from $32.25\left(\mathrm{Trt}_{1}\right)$ to 19.28 (Trt5). However the food conversion ratio (FCR) kept increasing from treatment (Tit $\left.{ }_{1}\right)$ (88.46) to 662.31 ( $\mathrm{Trt}_{5}$ ) with increasing stocking density. This assertion is confirmed with the positive FCR correlation coefficient $r=1.2964$ while the other growth and nutrient utilization parameters had negative correlations respectively. Also the measured physicochemical factors in the study showed significant responses $(P<0.05)$ to increasing stocking density. The dissolved oxygen $(D O)$ decreased with increasing stocking density, with a mean dissolved oxygen of $6.43 \mathrm{mg} /$ litre in treatment 5 containing 30 Juvenile Clarias gariepinus $/ 250$ litre bowl). Also the mean $\mathrm{pH}$ decreased from $7.73\left(\operatorname{Trt}_{1}\right)$ to $6.58\left(\operatorname{Trt}_{5}\right)$. Both the DO and $\mathrm{pH}$ values recorded were within the recommended tolerable ranges for all the treatments. However, an increasing pattern of variation was observed for ammonia increasing from 0.06ppm, (trt 1 to 0.122p.p.m. (trt 5 ), alkalinity increased from 30.70p.p.m. (Trt $\left.{ }_{1}\right)$ to 37.50p.p.m. (Trt5) and dissolved carbon dioxide increased from $9.27 \mathrm{mg} /$ litre ( trt $\left._{1}\right)$ to $27.57^{\circ} \mathrm{C}\left(\mathrm{Trt}_{4}\right)$ to $12.18 \mathrm{mg} /$ litre $\left(\mathrm{Trt}_{5}\right)$ while the mean water culture temperature also rose from $24.97^{\circ} \mathrm{C}\left(\operatorname{Trt}{ }_{1}\right)$ and $27.25^{\circ} \mathrm{C}$ for $\operatorname{Trt}_{5}$; this increase in temperature is also a result of the increasing stocking density of the juvenile Clarias gariepinus. All these increases (ammonia, alkalinity, $\mathrm{CO}_{2}$ and temperature) are indicators of increasing waste products with increasing number of fish in the bowls. This will eventually lead to fish mortalities (in the densely stocked treatments) and evidences of stunted growth alternatively is inevitable as a r' of crowding of the fish in a limited space.
\end{abstract}

\section{Introduction}

Aquaculture is the growing of aquatic organisms under controlled conditions (Bardach et al., 1972 (Sagua (1976) stated that aquaculture describes the art of introduction of fish into ponds, man made lakes, reservoirs and other impoundments and the management of the environments for the purpose of propagating the fish species for human benefits.

Huet (1972) describes aquaculture as the rational rearing of fish, including notably the control of growth and breeding. These definitions provide a basis for development especially when recent knowledge shows that the worlds natural stocks of fish, which although renewable, have finite limits which cannot be exceeded, even under the best management regimes.

The success of any fish production programme depends on adequate water quality management which ultimately determines the physiological status of the fish, internally and finally outwards physical status which we see as growth. Therefore, monitoring the optimum physico-chemical conditions such as temperature, $\mathrm{pH}$, alkalinity, dissolved oxygen, transparency and conductivity, enhances optimum fish growth and development. Inadequate feeding programmes and inability to maintain the required protein level will result to stunting of growth of the fish which results simply implies the fish is managing to survive because the required protein level have not been met. If this situation is coupled with increasing stocking density there will be acute competition for space as well and this may result in high mortality and poor fish yield.

The food and feeding habit of any fish varies with its age, locality and season. It could be due to occurrence and abundance of potential food materials, anatomical adaptations and size or age of the fish (Imevbore and Bakare, 1970). They also reported that many fish species have wide variable food habits and though they may appear to 
show good growth performance, these often seem to be conditioned by the preponderance of food items in the environment.

Clarias gariepinus is described as an omnivore with a higher propensity towards carnivorousity, especially control of Tilapia populations. It therefore feeds on a wide variety of food ranging from planktons, weeds, insects and insect larvae, crustaceans, snails, tadpoles, fish and fish remains. It therefore lives naturally in river bottoms and swamps (Hogendoorn, 1980).

The nutrient requirements of fish include, carbohydrate, proteins, fats, vitamins and minerals. Pillay (1990) observed that energy requirements of fish are supplied by carbohydrates, protein and fats, whereas Dupree and Hunner (1964) reported that fats and proteins are major energy sources and that the nutrient required by fish are utilized to meet the physiological needs of growth, repair and reproduction. Halver (1972), noted that the requirements of the five classes of nutrient in the diet of fish vary with fish size, water temperature and components of the ration. A deficiency or inadequacy of one or more of the above mentioned nutrients may result in a reduced performance rate or otherwise (Lovell, 1979).

In fish culture a water quality variable is any characteristics of water that affects the survival, reproduction, growth, production or management of fish in any way (Boyd and Lichtkoppler (1979). The water quality parameters include temperature, dissolved oxygen, ammonia, $\mathrm{pH}$ and turbidity.

Water quality broadly includes all physical, chemical and biological characteristics of water (Boyd, 1 979). Fish culturists are basically concerned with those aspects of water quality which regulate the suitability of water for holding or rearing fish, this basic understanding of water quality and its management becomes therefore necessary.

Fish growth depends greatly on the quality of the water used in the pond and the quality of the water depends upon where it comes from and what kind of soil it travels over. Testing the water quality means making sure that all the factors which related to water are right for the fish to enhance maximum growth and yield. These factors are:

(1) Chemical $\quad \begin{cases}\text { (b) } & \mathrm{pH} \\ \text { (c) } & \text { Total dissolved solids } \\ \text { (d) } & \text { Carbon dioxide } \\ \text { (e) } & \text { Alkalinity }\end{cases}$

(2) Physical

(c) $\begin{cases}\text { (a) } & \text { Temperature } \\ \text { (b) } & \text { Turbidity } \\ \text { Light penetration } \\ \text { (d) } & \text { Water colour } \\ \text { (e) } & \text { Planktons and weeds }\end{cases}$

Temperature is one of the most important environmental factors to be considered when selecting a particular species for pond culture because the body temperature, of fish varies with, and is almost the same as that of their environment. There is a normal range of temperature in the tropics of $15^{\circ} \mathrm{C}$ to $35^{\circ} \mathrm{C}$ to which fish are adapted.

Also oxygen levels below $3 \mathrm{mg} /$ litre for long periods of time may kill fish directly or lower their resistance to disease and parasites. The sensitivity of fish to low concentrations of dissolved oxygen varies between species, between different life stages (eggs, larvae and adults) and between different life processes (feeding, growth and reproduction) (Boyd, 1979).

Ammonia is released as an excretory product of fish occurring in two forms (a) Unionized form (NH which is toxic and (b) the ionized form ( $\mathrm{NH}$ which is non-toxic. The unionized form $\left(\mathrm{NH}_{3}\right)$ is more toxic when dissolved oxygen concentration is low, whereas when the concentration of carbon dioxide is high, toxicity reduces. The toxic levels for unionized ammonia for short-term exposure usually lie between 0.6 and $2.0 \mathrm{mg} / \mathrm{litre}$ for pond fish (Boyd, 1979).

Huet (1972) reported that the maximal acceptable p11 level varies with fish species and he recommended a pH 7 - 8 as the best for fish cultivation. Similarly, Boyd (1979) recorded that the water with pH values ranging between 6.5 and 9.0 at day break appear to be most suitable for fish production. Viveen et al. (1985) recommended a $\mathrm{pH}$ range of 6.5 to 8.0 for Clarias gariepinus. In view of the foregoing, the objectives of this study are as follows:

(I) To determine the implications of increasing stocking density of monocultured juvenile Clarias gariepinus on growth and nutrient utilization.

(2) To determine the implications of increasing stocking density of monocultured juvenile C/arias gariepinus on physico chemical factors of the culture pond.

(3) To determine the best stocking density for monocultured juvenile Clarias gariepinus. 


\section{Materials And Methods \\ EXPERIMENTAL FISH AND STOCKING DENSITY}

A total of 100 juvenile C/arias gariepinus of about $250-300 \mathrm{gm}$ average weight were stocked in five (250 litre each) experimental plastic bowls as follows (1) I was stocked with 10 juvenile Clarias gariepinus with an average weight of $20.90 \mathrm{gm}$ (2) Treatment 2 with 15 juvenile Clarias gariepinus with average weight $30.00 \mathrm{gm}$ (3) Treatment 3 with 20 juvenile Clarias gariepinus, average weight $38.60 \mathrm{gm}$ (4) Treatment 4 , with 25 juvenile C/arias gariepinus, with average weight of $41.25 \mathrm{gm}$ and (5) Treatment 5, with 30 juvenile Clarias gariepinus, with average weight $48.60 \mathrm{gm}$. The feeding of fish in each of the treatments was standardized at $3 \%$ body weight for a period of 10 weeks with initial acclimatization for 24 hours without feeding before the experiment started. Physico-chemical parameters were measured daily before changing the culture water with fresh water, while weekly averages were calculated and recorded. The fish in each treatment bowl were weighed weekly and feeding rates were adjusted weekly accordingly based on the $3 \%$ body weight and respective weekly change in weights of the treatment fish.

\section{FEEDING TRIALS ANI) GROSS COMPOSITION OF EXPERIMENTAL DIET}

The gross composition of the experimental diet is presented in Table 1. A $40 \%$ crude protein diet was compounded and fed to all the fishes in the 5 treatments based on their weekly weight changes at $3 \%$ body weight. The following ingredients were used - Yellow maize, palm kernel cake, soya meal, groundnut cake, bone meal, fish meal, oyster shell, growers premix and industrial salt. All dry feed ingredients were properly weighed, grinded and mixed thoroughly together. The fish were fed twice daily at 8.OOa.m. and 4.OOp.m. Feed weighed out to be fed daily were divided into two equal halves for this purpose.

Table I: Gross Composition of Experimental Diet Using 40\% Crude Protein
\begin{tabular}{|l|r|}
\hline Ingredient & Quantity (in Grams) \\
\hline Yellow maize & 10.00 \\
Palm Kernel & 10.00 \\
Soya meal & 25.00 \\
Groundnut Cake & 40.00 \\
Fish meal & 10.00 \\
Bone meal & 3.00 \\
Oyster shell & 1.25 \\
Grower premix & 0.25 \\
Industrial salt & 0.50 \\
\hline \multicolumn{1}{|r|}{ TOTAL } & $\mathbf{1 0 0 . 0 0}$ \\
\hline
\end{tabular}

\section{PROXIMATE ANALYSIS OF FISH}

Two extra juvenile Clariac gariepinus (apart from the 100 juvenile stocked) were used for inilial proximate analysis of the fish. Also one fish from each of the five treatments were used for the final proximate analysis of the fish at the end of the 10 week experimental period. Proximate analysis were carried out for crude protein, fat content, moisture content, ash and crude fibre according to A.O.A,C. (1990) methods.

\section{WATER QUALITY ANALYSIS}

The water quality parameters assessed in the course of the experiment were dissolved oxygen, $\mathrm{pH}$, temperature, dissolved carbon dioxide, ammonia and alkalinity. These parameters were measured using the Boyd (1979) methods. The $\mathrm{pH}$ level of the water was measured using a $\mathrm{pH}$ meter. Dissolved oxygen concentration was determined using winklers method. The temperature of the water used for the experiment was measured using mercury in glass thermometer calibrated in degree celsuis $\left({ }^{\circ} \mathrm{C}\right)$. Dissolved carbon dioxide was measured in $\mathrm{mg} /$ litre, ammonia in p.p.m and alkalinity was also measured in p.p.m.

\section{GROWTH AND NUTRIENT UTILIZATION PARAMETERS \\ (1) MEAN WEIGHT GAIN (MWG) GM \\ MGW $=\quad \underline{\text { Total fish weight gain }(\mathrm{gm})}$$$
\text { Number of fish }
$$ \\ (2) MEAN WEIGHT GAIN PER DAY (MWG1D) GM \\ MWG/D = Mean weight gain $(\mathrm{gm})$ \\ Number of experimental days \\ (3) MEAN WEIGHT GAIN PER WEEK (MWG/WK) GM \\ MWG/WK $=\quad$ Mean weight gain (gm) \\ (4) TOTAL PERCENTAGE WEIGHT GAIN (TPWG)\% \\ TPWG $=\quad \underline{\text { Total weight gain }} \times \underline{100}$}


(5) SPECIFIC GROWTH RATE (SGR)(\%)

SGR $\quad=\quad \underline{\log }_{\underline{c}} \underline{W_{2}} \frac{-\log _{c} \underline{W}_{1}}{\mathrm{~T} 2-\mathrm{T}_{\mathrm{I}}} \times \frac{100}{1}$

Where $\mathrm{W}_{1}=\quad$ Initial weight of fish $(\mathrm{gm})$

$\mathrm{W}_{2}=$ Final weight of fish $(\mathrm{gm})$

$\mathrm{T}_{2} \quad=\quad$ Time $\mathrm{t}_{2}$

$\mathrm{T}_{1} \quad=\quad$ Time $\mathrm{t}_{1}$

(6) TOTAL FEED INTAKE (GM)

This is obtained by summing up the amount of feed taken per week for each of the 5 treatments for the 10 week experimental period.

(7) FOOD CONVERSION RATIO (FCR)

$\mathrm{FCR}=$ Food Consumed

Weight gain

(8) GROSS EFFICIENCY OF FOOD CONVERSION (GEFC)

$\mathrm{GEFC}=\underline{\mathrm{I}} \quad \mathrm{x} \quad \underline{100}$

FCR 1

(9) PROTEIN INTAKE (P1) (GM)

$\mathrm{P} 1=\quad$ Total feed consumed $\mathrm{x}$ percentage protein

100

(10) PROTEIN EFFICIENCY RATIO (PER)

$\mathrm{PER}=$ Net weight gain

Protein Intake

(11) PRODUCTIVE PROTEIN VALUE (PPV)

$\mathrm{PPV}=\underline{\text { Increment in Body protein }(\mathrm{gm})}$

Protein Intake (gm)

(12) NITROGEN METABOLISM (Nm)

$$
\mathrm{Nm}=\frac{(0.549)(\mathrm{a}+\mathrm{b}) \mathrm{h}}{2}
$$

Where $a=$ Initial weight of fish

b Final weight of fish

$\mathrm{h}=$ Experimental period in days

(13) NET PROTEIN UTILIZATION (NPU)

$$
\mathrm{NPU}=\quad \underline{\mathrm{N}}_{\underline{\mathrm{b}}}-\mathrm{N}_{\underline{\mathrm{o}}}+\mathrm{N}_{\mathrm{N}_{\mathrm{b}}}
$$

Where $\mathrm{N}_{0}=$ Nitrogen content of fish before experiment

$\mathrm{N}_{\mathrm{b}}=$ Nitrogen content of fish after experiment

$1_{\mathrm{b}}=$ Nitrogen content of experimental diet

$\mathrm{N}_{\mathrm{m}}=$ Nitrogen metabolism

Nitrogen Content $=\underline{\text { Protein Intake }}$

$$
6.25
$$

CONDITION FACTOR (K)

Fultons Condition $(\mathrm{K})=\underline{100 \mathrm{~W}}$

Where $\mathrm{L}=$ Standard length

$$
\mathrm{L}^{3}
$$

$\mathrm{W}=$ Body weight

$\mathrm{K}=$ Condition factor

\section{STATISTICAL ANALYSIS}

Experimental results were subjected to the analysis of variance as described by Steel and Torrie (1960). Each stocking density level was considered as a treatment and a complete randomized design (ANOVA) was carried out to test for significance differences in the mean weight, growth rate and nutrient utilization as affected by the increasing stocking density, and also as the measured physico-chemical parameters in each treatment is affected by increasing stocking density. Prediction equations, correlation and regression analysis were also determined. 
Table 2 - Proximate Composition of Experimental Fish Before (Initial) and After (Final Experiment

\begin{tabular}{|c|c|c|c|c|c|c|}
\hline & $\begin{array}{l}\text { Crude } \\
\text { Protein \% }\end{array}$ & Fat \% & $\begin{array}{l}\text { Crude } \\
\text { Fibre \% }\end{array}$ & Ash \% & $\begin{array}{l}\text { Moisture } \\
\text { Content\% }\end{array}$ & N.F.E \\
\hline \multirow{6}{*}{$\begin{array}{l}\text { Before THE Experiment } \\
\text { Tr1 (10 Juv. C gar) }\end{array}$} & 70.05 & 5.23 & 2.09 & 12.88 & 7.86 & 1.80 \\
\hline & 75.18 & 4.64 & 1.36 & 10.51 & 8.11 & 0.20 \\
\hline & 73.91 & 4.56 & 1.49 & 10.84 & 7.96 & 1.24 \\
\hline & 72.71 & 4.45 & 1.64 & 10.98 & 7.85 & 2.37 \\
\hline & 71.21 & 4.34 & 1.73 & 11.13 & 7.70 & 3.89 \\
\hline & 70.19 & 4.27 & 1.82 & 11.31 & 7.64 & 4.77 \\
\hline
\end{tabular}

As shown in Table 2, initial fish crude protein was lowest with $70.05 \%$, this gradually increased from Treatment 5 (30 Juvenile Clarias gariepinus) with 70.19\% and this increased from $71.21 \%$ (Treatment 4) to $72.71 \%$ (Treatment 3 ) to $73.91 \%$ (Treatment 2) while the highest crude protein value of $75.18 \%$ was recorded in Treatment 1 with a stocking density of 10 Juvenile Clarias gariepinzts.

Fat content was highest in the initial fish (before the experiment) with a value of $5.32 \%$ much higher than the range $4.27 \% 4.64 \%$ recorded in the 5 treatments. The crude fibre, ash and N.F.E. followed a similar pattern with much higher initial values of $2.09 \%, 12.88 \%$ and $1.80 \%$ recorded respectively. However, higher moisture content $(8.11 \%, 7.96 \%$ and $7.85 \%)$ than initial $(7.86 \%)$ were recorded in Treatment 1,2 and 3 with much lower values than initial recorded for Treatment 4 and 5.

Table 3: Mean Weekly Physico-Chemical Parameters of the Culture Water Under Varying (Increasing Stocking Density of Juvenile C. ariepinus

\begin{tabular}{|c|c|c|c|c|c|c|}
\hline Treatment & $\mathrm{pH}$ & Temp. $\left({ }^{0} \mathrm{C}\right)$ & $\mathrm{DO} \mathrm{mg} / 1$ & Ammonia (p.p.m) & $\begin{array}{l}\text { Alkalinity } \\
\text { (p.p.m) }\end{array}$ & $\mathrm{CO}_{2} \mathrm{mg} / 1$ \\
\hline 0 & 7.80 & 25.50 & 6.60 & 0.005 & 30.00 & 9.20 \\
\hline TRT1 2 & 7.70 & 24.70 & 6.40 & 0.005 & 32.00 & 9.30 \\
\hline 104 & 7.60 & 25.10 & 6.80 & 0.007 & 31.00 & 9.30 \\
\hline 6 & 7.75 & 25.00 & 6.60 & 0.006 & 30.00 & 9.30 \\
\hline 8 & 7.65 & 24.70 & 6.40 & 0.007 & 30.00 & 9.30 \\
\hline 10 & 7.90 & 24.80 & 6.30 & 0.007 & 31.00 & 9.30 \\
\hline MEAN & 7.73 & 24.97 & 6.43 & 0.006 & 30.70 & 9.27 \\
\hline 0 & 7.60 & 26.20 & 6.20 & 0.008 & 33.00 & 9.60 \\
\hline TRT1 2 & 7.65 & 26.10 & 5.80 & 0.008 & 32.00 & 9.70 \\
\hline 154 & 7.70 & 26.00 & 6.10 & 0.008 & 33.00 & 9.60 \\
\hline 6 & 7.55 & 25.90 & 5.90 & 0.008 & 33.00 & 9.20 \\
\hline 8 & 7.40 & 26.30 & 6.20 & 0.007 & 34.00 & 9.80 \\
\hline 10 & 7.66 & 26.40 & 5.65 & 0.008 & 32.00 & 10.00 \\
\hline MEAN & 7.59 & 26.15 & 5.98 & 0.008 & 32.83 & 9.73 \\
\hline 0 & 7.50 & 26.80 & 5.70 & 0.095 & 33.00 & 10.20 \\
\hline TRT1 2 & 7.30 & 26.80 & 5.40 & 0.099 & 34.00 & 10.50 \\
\hline 204 & 7.45 & 26.40 & 5.60 & 0.091 & 34.00 & 10.40 \\
\hline 6 & 7.35 & 26.40 & 5.45 & 0.092 & 35.00 & 10.20 \\
\hline 8 & 7.50 & 26.90 & 5.38 & 0.102 & 34.00 & 10.30 \\
\hline 10 & 7.50 & 26.80 & 5.34 & 0.096 & 33.00 & 11.10 \\
\hline MEAN & 7.43 & 26.72 & 5.48 & 0.096 & 33.83 & 10.42 \\
\hline 0 & 7.00 & 27.50 & 5.45 & 0.105 & 35.00 & 11.60 \\
\hline TRT1 2 & 7.00 & 27.70 & 5.40 & 0.107 & 35.00 & 11.70 \\
\hline 254 & 7.15 & 27.60 & 5.35 & 0.105 & 36.00 & 11.80 \\
\hline 6 & 7.80 & 27.50 & 5.40 & 0.106 & 35.00 & 11.70 \\
\hline 8 & 7.00 & 27.60 & 5.40 & 0.106 & 36.00 & 11.10 \\
\hline 10 & 7.00 & 27.50 & 5.42 & 0.105 & 36.00 & 11.60 \\
\hline MEAN & 6.99 & 27.57 & 5.40 & 0.106 & 35.50 & 11.58 \\
\hline 0 & 6.50 & 27.20 & 5.20 & 0.124 & 37.00 & 12.00 \\
\hline TRT1 2 & 6.40 & 27.40 & 5.20 & 0.118 & 38.00 & 12.20 \\
\hline 304 & 6.60 & 27.20 & 5.10 & 0.121 & 38.00 & 12.20 \\
\hline 6 & 6.80 & 27.30 & 5.15 & 0.125 & 37.00 & 12.10 \\
\hline 8 & 6.20 & 27.20 & 5.25 & 0.122 & 38.00 & 12.30 \\
\hline 10 & 7.00 & 27.20 & 5.20 & 0.124 & 37.00 & 12.30 \\
\hline MEAN & 6.58 & 27.25 & 5.18 & 0.122 & 37.50 & 12.18 \\
\hline
\end{tabular}

As shown in Table 3 the $\mathrm{pH}$ values decreased with increasing stocking density from Treatment 1 Treatment 5 that is $\left(7.73\left(\operatorname{Trt}_{1}\right)>7.59\left(\operatorname{Trt}_{2}\right)>7.43\left(\mathrm{Trt}_{3}\right)>6.99\left(\mathrm{Trt}_{4}\right)>6.58\left(\mathrm{Trt}_{4}\right)\right.$. Also the dissolved oxygen decreased in each treatment bowl water from $6.43 \mathrm{mg} /$ litre in Treatment 1 to $5.18 \mathrm{mg} /$ litre in Treatment 5 containing the highest number of juvenile fish (30 Juvenile Clarias in the bowl). The mean temperature change in the 5 treatments were within a narrow range of $24.97-27.25^{\circ} \mathrm{C}$, that is the mean temperature increasing gradually with increasing stocking density from Treatment $1\left(24.97^{\circ} \mathrm{C}\right.$ to $27.25^{\circ} \mathrm{C}$ in Treatment 5; while remaining constant in Treatment 5 with a value of $27.25^{\circ} \mathrm{C}$. 
Also the ammonia, alkalinity and dissolved carbon dioxide increased with increasing stocking density from Treatment 1 to 5 . Ammonia mean values increased from $0.006 \mathrm{ppm}$ ( $\operatorname{Trt} 1$ ) to $0.122 \mathrm{ppm}$ (Trt 5), alkalinity mean values increased from $30.70 \mathrm{ppm}$ in Treatment 1

- 37.50pprn in Treatment 5. Also the mean dissolved carbon dioxide of the culture water in each treatment increased from $9.27 \mathrm{mg} / \mathrm{litre}$ in Treatment 1 to $12.18 \mathrm{mg} / \mathrm{litre}$ in Treatment 5 .

Significant differences $(\mathrm{P}<0.05)$ exist between all the treatments for .,all the measured parameters viz:- Mean, $\mathrm{pH}$, temperature, dissolved oxygen, ammonia, alkalinity and dissolved carbon dioxide.

Table 4 - Growth and Nutrient Utilization Pattern of Juvenile Clarias gariepinus under Varying (Increasing) Stocking Density

\begin{tabular}{|l|c|c|c|c|c|}
\hline Treatment & I & II & III & IV & V \\
\hline Experimental period (days) & 70 & 70 & 70 & 70 & 70 \\
\hline No. of fish stocked & 10 & 15 & 20 & 25 & 30 \\
\hline Mean Initial Weight (gm) & 2.09 & 2.00 & 1.93 & 1.65 & 1.62 \\
\hline Mean Final Weight (gm) & 9.03 & 7.87 & 6.76 & 5.49 & 4.65 \\
\hline Mean Weight Gain (gm) & 6.94 & 5.89 & 4.83 & 3.84 & 3.03 \\
\hline Mean Daily Weight gain per day & 0.099 & 0.084 & 0.069 & 0.055 & 0.043 \\
\hline Specific Growth Rate & .20 & 0.190 & 0.018 & 0.017 & 0.015 \\
\hline Total feed intake & 59.29 & 104.79 & 140.77 & 153.58 & 172.27 \\
\hline Mean feed intake per day & 0.847 & 1.497 & 2.011 & 2.194 & 2.461 \\
\hline Feed Conversion ratio & 88.46 & 185.91 & 325.93 & 448.54 & 662.31 \\
\hline Gross feed conversion efficiency (\%) & 1.13 & 0.54 & 0.31 & 0.22 & 0.15 \\
\hline Protein lntake (gm) & 68.91 & 61.40 & 56.30 & 41.90 & 23.90 \\
\hline Protein Efficiency Ratio & 0.29 & 0.14 & 0.09 & 0.06 & 0.04 \\
\hline Productive Protein Value & 0.24 & 0.09 & 0.05 & 0.02 & 0.002 \\
\hline Nitrogen Metabolism & 213.70 & 190.03 & 166.98 & 137.20 & 120.48 \\
\hline Net Protein Utilization & 32.25 & 28.67 & 26.78 & 21.98 & 19.28 \\
\hline
\end{tabular}

Increasing stocking densities $(10,15.20,25$ and 30 Juvenile C/arias gariepinus) from Treatment $1-5$ caused (a) decreased specific growth rate (SGR) from $0.20-0.15$ (Treatment 1 - 5) (b) decreased mean weight gain from $6.94 \mathrm{gm}-3.03 \mathrm{gm}$ (Treatment I - 5) (c) decreased mean daily weight gain per day from 0.099 to 0.043 (d) decreased protein intake $68.91 \mathrm{gm}-23.90 \mathrm{gm}$ (e) decreased gross feed conversion efficiency (\%) from $1.13-0.15(0$ decreased Protein efficiency ratio (PER) from $0.29-0.04$ and also decreased productive protein value (PPV). Nitrogen metabolism (Nm) and Net protein utilization (NPU) also following the same pattern of variation.

However feed conversion ratio (FCR) increased from 88.46 to 662.31 in Treatment I -5 , along with mean feed intake per day from 0.847 to 2.461 (Treatment $1-5$ ). Also the total feed intake increased in a similar pattern.

Table 5 -Linear Equations Coefficients of Determination (r) Relating Each of the Dependent Variables to the Independent Variable (Stocking Density)

\begin{tabular}{|c|c|c|c|c|}
\hline $\begin{array}{l}\text { Independent } \\
\text { Variable (Y) }\end{array}$ & $\begin{array}{l}\text { Dependent } \\
\text { Variable }(\mathrm{X})\end{array}$ & Prediction Equation & $\mathbf{R}$ & $\mathbf{R}^{2}$ \\
\hline Stocking Density & SGR & $18.2884+0.9427 X$ & -0.1957 & 0.0382 \\
\hline “" & PPV & $43.525-30.098 X$ & -0.9190 & 0.8447 \\
\hline “ & FCR & $26.6577-30.098 \mathrm{X}$ & 1.2964 & 1.6808 \\
\hline “" & PI & $17.1026+0.5743 X$ & -0.8154 & 0.657 \\
\hline “ & GEFC & $14.8949+0.9528 \mathrm{X}$ & -0.8154 & 0.6049 \\
\hline “" & PER & $0.59+14.90 \mathrm{X}$ & -0.8899 & 0.7919 \\
\hline$"$ & MWG & $-0.1528+0.414 X$ & -0.6693 & 0.448 \\
\hline
\end{tabular}

KEY: $\quad$ SGR $=\quad$ Specific Growth Rate

$\begin{array}{lll}\text { FCR } & = & \text { Food Conversion Ratio } \\ \text { PPV } & = & \text { Productive Protein Value } \\ \text { MWG } & = & \text { Mean Weight Gain } \\ \mathrm{P} 1 & = & \text { Protein Intake } \\ \text { PER } & = & \text { Protein Efficiency Ratio } \\ \text { GFCE } & = & \text { Gross Food Conversion Efficiency } \\ \mathrm{SD} & = & \text { Stocking Density } \\ \mathrm{R} & = & \text { Coefficient of Correlation } \\ \mathrm{R}^{2} & = & \text { Coefficient of Determination }\end{array}$

As shown in Table 5 the negative coefficient of correlation recorded for SGR $(R)=-0.1957$, PPV $(R)-0.9190$, $\mathrm{P} 1(\mathrm{R})=-0.8106, \operatorname{GEFC}(\mathrm{R})=-0.8154$, PER $(\mathrm{R})=-00.8899$ and MWG $(\mathrm{R})=-0.6693$ implies that all these growth and nutrient utilization parameters mentioned decreased with increasing stocking density. However it is 
only the FCR $(\mathrm{R})=1.2964$ (which is positive) that implies it increases with stocking density. This probably implies an unsuitable culture environment due to increasing stocking density does resulting in poor growth and nutrient utilization.

\section{Discussion}

The $40 \%$ crude protein diet compounded and fed to the fish in all the five treatments actually met their protein requirement, however these factors were strongly dependent on the stocking density treatments. While all the final crude protein values recc were higher than the initial values (Table 2). The crude protein value of $70.19 \%$ recorded in Treatment 5 with the highest stocking density (30 Juvenile C/arias gariepinus) was almost at par with the initial fish crude protein of $70.05 \%$ while higher values were recorded for Trtl $(75.15 \%)>\operatorname{Trt} 2$ $(73.91 \%)>\operatorname{Trt} 3(72.71 \%)>\operatorname{Trt} 4(71.21 \%)>\operatorname{Trt} 5(70.19 \%)$.

A similar trend was followed in the SGR (decreasing from 0.20 (Trtl) to 0.015 (Trt 5), MWG (decreasing from 6.94 (Trtl) to 3.03 (Trt 5), PER (decreasing from 0.29 (Tfll) to 0.04 (Trt 5), PPV (from 0.24 (Trt I) to 0.04 (Trt 5) and NPU (from 32.25 (Trt 1) to 19.28 (Trt 5). However the food conversion ratio (FCR) kept increasing from Trt 1 (88.46) to 662.31 (Trt 5) with increasing stocking density (Table 4). This assertion is further confirmed with FCR having a positive correlation $r=-1.2964$ while the other growth and nutrient utilization parameters had negative correlation coefficients (Table 5).

In this study dissolved oxygen decreased with increasing stocking density (Table 3) with the highest mean Dissolved oxygen recorded in treatment I (with 10 Juvenile Clarias gariepinus) with a mean value of $6.43 \mathrm{mg} / \mathrm{litre}$ decreasing to $5.18 \mathrm{mg} / \mathrm{litre}$ in treatment 5 (with 30 Juvenile Clarias gariepinus stocked). Although this observation is within the range of 6.5- 8.0 proposed by Viveen et al, (1985) for Clarias gariepinus and in line with other parameters discussed higher stocking density will always cause a reduction in dissolved oxygen of the culture medium and this will definitely reduce growth and nutrient utilization pattern in Clarias gairepinus.

A similar pattern and same preposition goes for the mean p1-I recorded during the study (decreasing from 7.73 (Trt 1) to 6.58 (Trt 5), although this range corresponded to the desirable $\mathrm{pH}$ of $7.0-8.0$ best for fish culture asserted by Huet (1972). While an increasing pattern of variation was observed for ammonia (increasing from 0.06p.p.m (Trt 1) to 0.122p.p.rn (Trt 5) alkalinity (increasing from 30.70p.p.m to 37.50p.p.m (Tr 5), dissolved carbon dioxide (increasing from $9.27 \mathrm{mg} /$ litre (Trt 1) to $12.18 \mathrm{mg} / \mathrm{litre}$ ) (Trt 5). All these values which increased with increasing stocking density will not promote growth and nutrient utilization.

Also a similar increase in temperature virtually remained constant in treatment $1\left(24.97^{\circ} \mathrm{C}\right.$ to $27.57^{\circ} \mathrm{C}(\mathrm{Trt} 4)$ while the temperature virtually remained constant in treatment 5 with a value of $27.25^{\circ} \mathrm{C}$. This observation may be explained that the increasing stocking density partially resulted in the increase in temperature/temperature variations since all the treatments were maintained under the same ambient temperature and possibly an indication of increasing inputs (waste products) in the culture water.

\section{Conclusion}

Increasing stocking density of Clarias gariepinus will cause a continuous drop in $\mathrm{pH}$ (as the number of fish stocked increase) thus making the $\mathrm{pH}$ slightly acidic and thus falling short of the $\mathrm{pH}$ for fish culture, which may thus result in fish mortality.

The increasing values of other physico-chemical parameters measured (viz: dissolved carbon (ioxide, alkaliniiy, and ammonia values) with increasing stocking density is responsible for the gradual drop in $\mathrm{pH}$ and dissolved oxygen values and consequently Crowding" of the fish in a limited space resulted in the increased water temperature gradually) due to increased activity of the fish and increasing waste products to cope with in the culture water.

\section{References}

[1]. A.O.A,C. (Association of Official Analytical Chemists) (1990). Official method of Analysis of the AOAC (W. Horwithz ed.) 13th edition AOAC Washington, D.C.

[2]. Bardach, J.F., Ryther, J.H. and Martarney,.W.D. (1972): Aquaculture: The Farming and husbandry of fresh water and marine organisms. Wiley lntgerscience, New York.

[3]. Boyd, C.E. (1979): Water quality in warm water fish ponds. Auburn University, Agricultural Expt. Station. Auburn Alabama. 359pp.

[4]. Boyd and Lichtkoppler (1979): Water quality management in pond fish culture. International Centre for Aquaculture, Agricultural Experimental Station, Auburn University 2Opp.

[5]. Dupree, H.K. and Huner, J.V. (1964b): Nutrition, Feeds and Feeding practices. The status of warm water fish farming and in fish farming research. Published U.S. Department of Fish and Wildlife Services.

[6]. Halver, J.E. (1976a): Formulating practical diets for fish. Fish Res. Board Canada 33:1032 - 1039.

[7]. Hogendoorn, 1-1. (1980): Controlled propagation of the African Catfish, Clarias lazera (C \& V) I Feeding and growth of fish. Aquaculture, 21: $233-241$.

[8]. Huet, M. (1972): Textbook of fish culture. Breeding and Cultivation of fishes, translated by H. Kohn. Fishing News (Books) Ltd., Surrey England 436pp. 
[9]. Imevbore, A.M.A. and Bakare, 0. (1970): The food and Feeding Habits of non Cichlid fishes of the River Niger in the Kainji Reservoir Area, Kainji Lake Studies Vol. 1 Ecology: Edited by S.A. Visser, pp. 44 - 64.

[10]. Lovell, R.T. (1977): Feeding practices for Channel Catfish. Fish Ann. Rep. Na. Agric. Exp. Sta. Auburn Univ. 37pp.

[11]. Pillay, T.V.R. (1990): Aquaculture: Principles and Practices. Fishing News Book, Blackwell Scientific Publications Ltd., Oxford, England.

[12]. Sagua, V.0. (1976): Aquaculture and Fishery development in Nigeria. A review paper in proceeding of $12^{\circ}$ Annual Conference of Agricultural Society of Nigeria fle-Ife, 1976.

[13]. Steel, R.G.D. and Torrie, J.H. (1960): Principle and procedure of Statistics. McGraw Hill Book Co. Inc. New York.

[14]. Viveen, W.J.A.R., Richter, C.J. Van oral P., James J. Huismann, E.A. (1985): Practical Manual for the culture of the African Catfish Clarias gariepinus. Netherlands. 